\title{
Relationship Between Insulin-Receptor Substrate 1 and Langerhans' Islet in a Rat Model of Type 2 Diabetes Mellitus
}

\author{
WAHYUNI LUKITA ATMODJO ${ }^{1,2}$, YOUNG OTHIWI LARASATI ${ }^{1}$, JUANDY JO ${ }^{3}$, \\ RISKA NUFIKA $^{1}$, STEFFI NAOMI ${ }^{4}$ and IMELDA WINOTO ${ }^{1}$ \\ ${ }^{1}$ Department of Immunopathology, Mochtar Riady Institute for Nanotechnology, Tangerang, Indonesia; \\ ${ }^{2}$ Department of Anatomy, Faculty of Medicine, Universitas Pelita Harapan, Tangerang, Indonesia; \\ ${ }^{3}$ Program of Biology, Faculty of Science and Technology, Universitas Pelita Harapan, Tangerang, Indonesia; \\ ${ }^{4}$ Department of Biomedicine, Indonesia International Institute for Life Science, Jakarta, Indonesia
}

\begin{abstract}
Background/Aim: In vivo studies on pathogenesis of type 2 diabetes mellitus (T2DM) have been reported, however, the relationship between insulin-receptor substrate 1 (IRS1) and the area of Langerhans' islets was unknown. Therefore, a correlation between both parameters was assessed. Materials and Methods: Diabetic groups were fed with a high-fat diet (HFD) and injected with three different doses of streptozotocin, namely 25, 35 and $45 \mathrm{mg} / \mathrm{kg}$, and compared to a control group after 9 weeks. Results: Administration of HFD/streptozotocin increased the level of fasting blood glucose but reduced the level of IRSI and the area of Langerhans' islets in diabetic groups. The coefficient of correlation between IRS1 and area of Langerhans' islets was 0.259 ( $p=0.232)$. In addition, the coefficient of correlation for fasting blood glucose with the area of Langerhans' islets and IRS1 was -0.520 ( $p=0.011)$ and -0.603 ( $p=0.002$ ), respectively. Conclusion: The reduction of IRSI was weakly correlated with the destruction of Langerhans' islets, suggesting there is an intermediate step between both parameters.
\end{abstract}

The prevalence of diabetes mellitus for all age groups worldwide was estimated to be $4.4 \%$ in 2030 , in which it will increase in people above 65 years old (1). In Asia, the dramatic rise of diabetes is largely due to the rise in risk factors, including overweight and obesity (2). According to the fact that

This article is freely accessible online.

Correspondence to: Wahyuni Lukita Atmodjo, MD, Ph.D., Department of Anatomy, Faculty of Medicine, Universitas Pelita Harapan, Lippo Karawaci, Tangerang 15810, Indonesia. Tel: +62 2154230, Fax: +62 2154233, e-mail: wahyuni.atmodjo@uph.edu

Key Words: Diabetes mellitus, Wistar rats, high-fat diet, streptozotocin, insulin-receptor substrate 1, Langerhans' islet. the prevalence of diabetes rises every year, numerous studies are conducted to investigate its pathophysiology and therapy. There are two main types of diabetes: type 1 diabetes mellitus, which is an autoimmune disease with damage of pancreatic $\beta$ cells, and type 2 diabetes mellitus (T2DM), which is characterized by insulin resistance when the body is unable to use insulin and $\beta$-cells are unable to compensate $(3,4)$.

Physiologically, insulin binds to its receptor, which belongs to the superfamily of receptor tyrosine kinases. This results in phosphorylation of specific tyrosine residues, which bind to phosphorylated juxta membrane domain residue tyrosine 960, a family of large docking proteins called insulin-receptor substrate (IRS). There are two IRS proteins in humans: IRS1 and IRS2, which play a role in the insulin-signaling pathway. The studies by Rondinone et al . (5) and Pederson et al. (6) demonstrated that IRS1 is the main docking protein for phosphoinositide-3-kinase, which is associated with an increase in glucose uptake by cells. Consequently, levels of insulin in cells can be assessed by measuring the tyrosine phosphorylation of IRS1, as a downstream product of insulin binding to cell receptors (7). In addition, decreasing levels of IRS1 have been observed in various animal models of insulin resistance, suggesting its role in the development or progression of T2DM (8-12).

T2DM characterized by insulin resistance occurs in the cells of muscles, liver and fat tissue (13). In insulin resistance, insulin binds to its receptor but the signal is not sent into the cell, causing no glucose uptake and increasing blood glucose's level. The proportion of insulin resistance compared with $\beta$-cell dysfunction differs among individuals, in which some primarily have insulin resistance and a minor defect in insulin secretion, while others have slight insulin resistance but are primarily lacking insulin secretion (14). In the early phase of T2DM, it was found that the mass of $\beta$ cells in the Langerhans' islet expands in order to increase insulin secretion. However, when the disease progressed, approximately half of the $\beta$-cells disappeared (15). In animal 


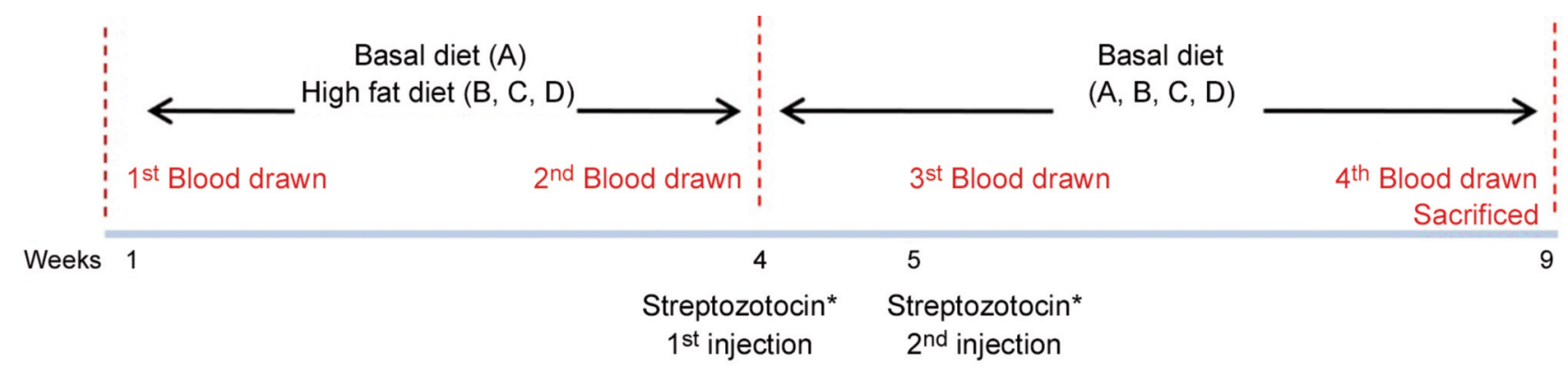

Figure 1. The experimental design of this study. *At 25, 35 or $45 \mathrm{mg} / \mathrm{kg}$ bodyweight.

models, volume density of the islets, islet diameter, and $\beta$ cell number have been assessed in order to study the pathophysiology of T2DM (16).

Several investigators have reported that rats given a single high-dose injection of streptozotocin intraperitoneally or intravenously endured rapid chemical destruction of the pancreatic $\beta$-cells (17-23). Furthermore, other groups demonstrated that the combination of a high-fat diet (HFD) and low-dose injection of streptozotocin in rats served as an alternative animal model for T2DM with the characteristic of insulin resistance $(17,18)$. Numerous in vivo studies on pathogenesis of T2DM by using animal models receiving an HFD combined with multiple injections of a low dose of streptozotocin have been reported for the study of prevention and treatment of diabetes (17-23). However, the relationship between IRS1, an important element in insulin-signaling pathways, and Langerhans' islet area has not been fully elucidated. In the current study, we assessed the correlation between IRS1 and the area of Langerhans' islets in a rat model of T2DM.

\section{Materials and Methods}

Animal husbandry and treatment. All animal experimental protocols were conducted in Animal Facility of Mochtar Riady Institute for Nanotechnology in accordance with the National Research Council Guide for the Care and Use of Laboratory Animals. This study protocol was approved by Mochtar Riady Institute for Nanotechnology Ethical Committee, Indonesia (02.1505027). A total of 32 male Wistar rats at 6 weeks old were purchased from PT. Indoanilab (Bogor, Indonesia). All animals were housed in polycarbonate plastic cages (two rats per cage) with wood-shaving bedding, maintained in a controlled room at temperature $25 \pm 2^{\circ} \mathrm{C}$, with humidity $50 \pm 10 \%$, and $12 / 12 \mathrm{~h}$ of light-dark cycles with $a d$ libitum access to food and water. Male Wistar rats were used as they are widely used as diabetic animal model and male pancreatic islet $\beta$-cells are more prone than female ones in exhibiting streptozotocin-induced cytotoxicity. Furthermore, female rats are resistant to the effects of low-dose streptozotocin (21, 23-25).

Following 1 week of acclimatization, rats were randomly divided into a control group $(n=8)$ and three different treated groups (total $\mathrm{n}=24$ ). Federer formula was used to determine the number of samples for each group after adjustment with $80 \%$ successful rate in inducing diabetes. The animal model, experimental design and HFD composition in this study were performed according to Zhang et al. (21) and Furman et al. (10) with modification (Figure 1). The rats in the control group were fed with regular basal diet based on AIN76 rodent diet formula (67.7\% of carbohydrate, $11.5 \%$ of lipid and $20.8 \%$ of protein) and had intraperitoneal injection with saline. The diabetic groups were fed with an HFD: $48 \%$ of carbohydrate, $22 \%$ of lipid and $20 \%$ of protein (Food Technology Laboratory, Bogor Agricultural University, Bogor, Indonesia) for 4 weeks and were further divided into three different doses of streptozotocin: 25, 35 and $45 \mathrm{mg} / \mathrm{kg}$ body weight (BW), with $\mathrm{n}=8$ in each group. The streptozotocin injections were administered intraperitoneally twice within a 1 -week interval. The blood was collected at week $0,4,5$ and 9 from the tail after 10 hours of fasting at night and checked for fasting blood glucose using Easy Touch Glucose test strip (CEI Technology Inc., Guishan, Taoyuan, Taiwan, ROC). Four weeks after the second injection of streptozotocin, at week 9, all rats were sacrificed by exsanguination after anesthesia using a combination of 40-80 mg/kg BW ketamine and 5-10 mg/kg BW xylazine. The liver was collected and stored in phosphate buffered saline for protein analysis. The pancreas was removed and fixed in 10\% buffered neutral formalin for histological analysis.

Histological analysis. Fixed pancreas in 10\% buffered neutral formalin was dehydrated in a series of increasing alcohol concentration (70-100\%), immersed in xylene and embedded in paraffin. The paraffin block of pancreas was for $4 \mu \mathrm{m}$ thickness using a microtome, then the sections were deparaffinized in xylene and rehydrated through a series of decreasing ethanol concentration (100-70\%) and stained with hematoxylin and eosin solution. Histological specimens of pancreas were observed and the area of Langerhans's islets were measured using ZEN microscope software (Zeiss, Oberkochen, Germany) at a magnification of $100 \times$.

Protein isolation and analysis. Liver protein stored in phosphatebuffered saline, weighed 50-100 g and transferred into radioimmunoprecipitation assay buffer (Abcam, Cambridge, UK), after adding with proteinase inhibitor to prevent protein degradation. Supernatant was collected using a combination freeze-thaw method and mechanical grinding using a tissue homogenizer. Total protein concentration in the supernatant was measured using Bradford Kit (Bio-Rad, CA, USA). Levels of tyrosinephosphorylated IRS1 were measured using My BioSource Elisa Detection Kit (San Diego, CA, USA). 
Table I. Fasting blood glucose (FBG) levels in diabetic groups. The average FBG level in three diabetic groups on a high-fat diet injected with streptozotocin at 25, 35 and $45 \mathrm{mg} / \mathrm{kg}$ body weight were compared at week 0 (before treatment) and week 9 after treatment.

\begin{tabular}{|c|c|c|c|c|c|c|}
\hline \multicolumn{7}{|c|}{ FBG, $\mathrm{mg} / \mathrm{dl}$} \\
\hline Group & Streptozotocin & Time point & $\mathrm{n}$ & Mean \pm SD & Range & $p$-Value \\
\hline \multirow[t]{2}{*}{1} & $25 \mathrm{mg} / \mathrm{kg}$ & Week 0 & 8 & $127.63 \pm 5.90$ & $121-137$ & \\
\hline & & Week 9 & 8 & $141.50 \pm 26.68$ & $111-191$ & $0.248 v s$. Week 0 \\
\hline \multirow[t]{2}{*}{2} & $35 \mathrm{mg} / \mathrm{kg}$ & Week 0 & 8 & $121 \pm 13.31$ & $96-137$ & \\
\hline & & Week 9 & 8 & $233.50 \pm 81.88$ & $135-394$ & $\begin{array}{l}\mathbf{0 . 0 0 1} \text { vs. Week } 0 \\
0.10 \text { vs. } 25 \mathrm{mg} / \mathrm{kg}\end{array}$ \\
\hline \multirow[t]{2}{*}{3} & $45 \mathrm{mg} / \mathrm{kg}$ & Week 0 & 8 & $121.25 \pm 7.07$ & $110-133$ & \\
\hline & & Week 9 & 8 & $353.75 \pm 94.03$ & $132-418$ & $\begin{array}{c}\mathbf{0 . 0 0 1} \text { vs. Week 0 } \\
\mathbf{0 . 0 0 5} \text { vs. } 25 \mathrm{mg} / \mathrm{kg} \\
\mathbf{0 . 0 2 7} \text { vs. } 35 \mathrm{mg} / \mathrm{kg}\end{array}$ \\
\hline
\end{tabular}

Statistically significant $p$-values are shown in bold.

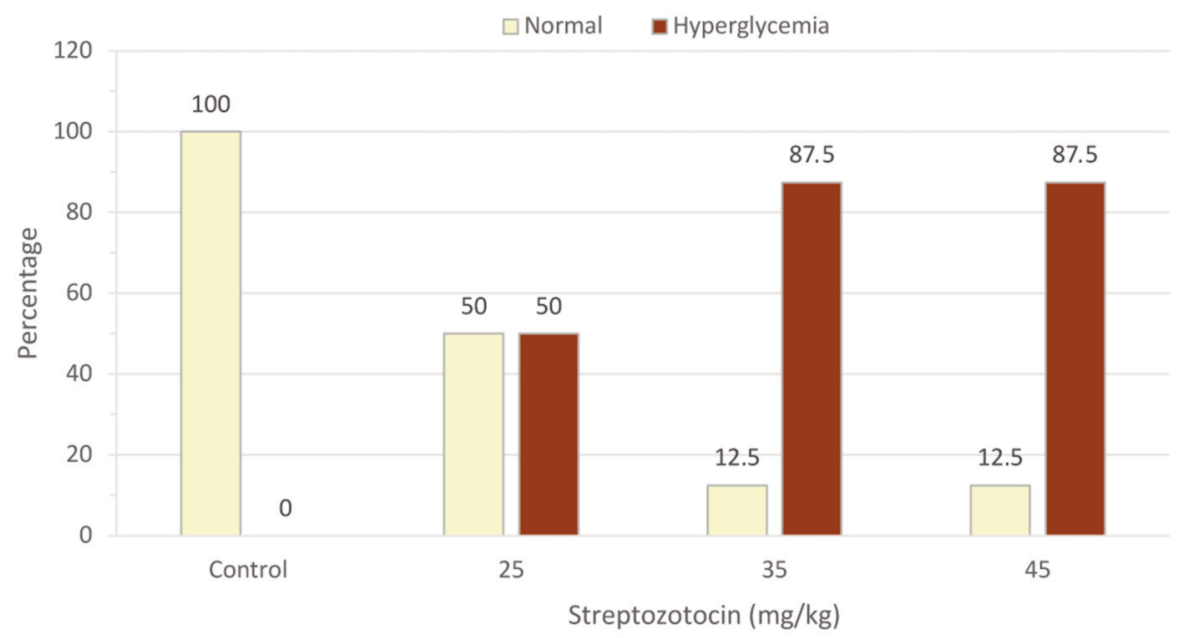

Figure 2. Proportion of hyperglycemic rats at week 9 after treatment with high-fat diet with and without streptozotocin. Glucose was measured in blood from the tail vein after 10 hours of fasting at night. The proportions of normal and hyperglycemic rats were determined in each group using a cut-off value of $140 \mathrm{mg} / \mathrm{dl}$ as published elsewhere (21).

Statistical analysis. Data were analyzed for normality based on Sapiro-Wilk test of normality. Mean differences in fasting blood glucose (FBG), IRS1 and area of Langerhans' islets were analyzed with Mann-Whitney using SPSS software version 23 (IBM, Armonk, NY, USA). The correlation among variables were analyzed with Spearman's Rho correlation, with $p<0.05$ set as statistical significance.

\section{Results}

Dose-dependent increment in FBG of T2DM rats. Following 10 hours of fasting, blood was taken from rat tails and glucose measured by test strips. The FBG levels at week 9 of rats injected with streptozotocin of $25 \mathrm{mg} / \mathrm{kg}, 35 \mathrm{mg} / \mathrm{kg}$ and $45 \mathrm{mg} / \mathrm{kg}$ were $141.5 \pm 26.7 \mathrm{mg} / \mathrm{dl}, 232.5 \pm 81.8 \mathrm{mg} / \mathrm{dl}$ and $353.75 \pm 94.0 \mathrm{mg} / \mathrm{dl}$, respectively. Average levels of FBG in rats receiving streptozotocin of $35 \mathrm{mg} / \mathrm{kg}$ and $45 \mathrm{mg} / \mathrm{kg}$ were statistically significantly higher at week 9 than at week 0 (Table I; $p=0.001$ ). The comparison between diabetic groups were analyzed using non-parametric Mann-Whitney test and showed statistically significantly higher FBG levels at week 9 between rats treated with 35 to $45 \mathrm{mg} / \mathrm{kg}$ compared with $25 \mathrm{mg} / \mathrm{kg} \quad(p=0.005$ and $p=0.027$, respectively (Table I). Using a cut-off value for FBG of 140 $\mathrm{mg} / \mathrm{dl}$, as described previously (21), there were no hyperglycemic rats in the control group, while in groups injected with streptozotocin at $25 \mathrm{mg} / \mathrm{kg}, 35 \mathrm{mg} / \mathrm{kg}$ and 45 $\mathrm{mg} / \mathrm{kg}$ the proportion was $50.0 \%, 87.5 \%$ and $87.5 \%$, respectively (Figure 2). 

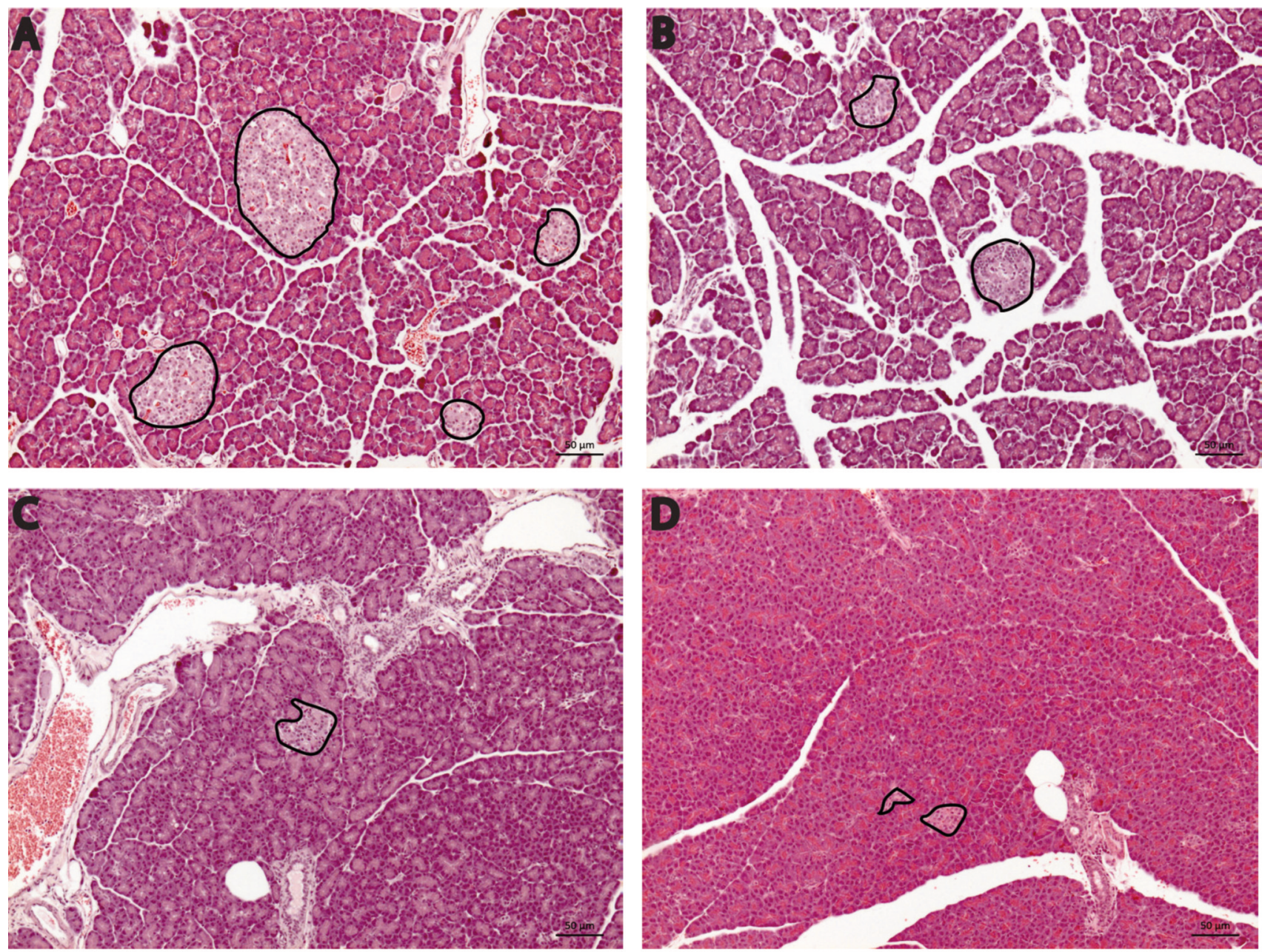

Figure 3. Sections of rat pancreas were stained using hematoxylin-eosin and captured at 100x magnification. Langerhans' islets are outlined in bold. Rats of the control group presented an elliptical shape with a clear boundary of Langerhans' islets (A). Pancreatic section of diabetic group treated with (B) 25, (C) 35 and (D) $45 \mathrm{mg} / \mathrm{kg}$ body weight of streptozotocin showed Langerhans' islets to be of smaller size, irregular shape and unclear boundaries.

Dose-dependent reduction in area of Langerhans' islets. As shown in Figure 3A, Langerhans' islets were dispersed evenly in control pancreas. The pancreatic sections stained with hematoxylin and eosin showed pancreatic lobules composed of grape-like clusters of exocrine cells and endocrine islets of Langerhans containing $\beta$-cells. Within the control groups, the size of islets was relatively large and their shapes were oval or round with a clearly defined outline. Figure 3B-D show that Langerhans' islets displayed irregular shape and size in the diabetic groups at all three doses of streptozotocin. The average area of Langerhans' islets in control rats were subsequently compared to diabetic groups treated with three different doses of streptozotocin. The decline in the area of Langerhans' islets suggested there was a dose-dependent reduction. Indeed, rats injected with streptozotocin at 45 $\mathrm{mg} / \mathrm{kg}$ had the smallest area of Langerhans' islet as compared to that of the control group ( $p=0.015$; Table II).

Dose-dependent reduction in hepatic expression of IRS1. The response of hepatic cells to the presence of insulin was assessed by measuring levels of tyrosine-phosphorylated IRS1, as a downstream product of insulin-bound cellular receptors. Of note, one datum of IRS1 in the group treated with streptozotocin at $45 \mathrm{mg} / \mathrm{kg}$ was considered as an outlier and omitted from the analysis. Table III shows the levels of IRS1 in control rats and diabetic groups treated with streptozotocin decreased to $1,103.99 \pm 218.76 \mathrm{pg} / \mathrm{ml}$, $901.77 \pm 105.53 \mathrm{pg} / \mathrm{ml}$ and $868.03 \pm 143.55 \mathrm{pg} / \mathrm{ml}$, respectively. Furthermore, levels of IRS1 in diabetic groups injected with streptozotocin at 35 and $45 \mathrm{mg} / \mathrm{kg}$ were the lowest. This 
Atmodjo et al: Linear Correlation Between IRS1 and Area of Langerhans' Islets in Diabetic Rats

Table II. Total area of Langerhans' islets at week 9. The area of pancreatic Langerhans' islets at 100x magnification was calculated and analyzed using ZEN microscope software. The differences between groups were analyzed using Mann-Whitney two-independent sample test.

\begin{tabular}{lccccc}
\hline \multicolumn{5}{c}{ Average area of islets of Langerhans, $\mu \mathrm{m}^{2}$} \\
\hline Group & Treatment & $\mathrm{n}$ & Mean \pm SE & Range & $p$-Value $v s$. Control \\
\hline 1 & Control & 8 & $752,436.95 \pm 75,161.25$ & $44.52-728.81$ & \\
2 & $25 \mathrm{mg} / \mathrm{kg}$ Streptozotocin & 8 & $479,438.12 \pm 98,204.47$ & $183.28-874.26$ & 0.834 \\
3 & $35 \mathrm{mg} / \mathrm{kg}$ Streptozotocin & 8 & $310,455.18 \pm 116,112.36$ & $83.45-979.49$ & 0.141 \\
4 & $45 \mathrm{mg} / \mathrm{kg}$ Streptozotocin & 8 & $131,751.06 \pm 25,897.96$ & $44.97-265.28$ & $\mathbf{0 . 0 1 5}$ \\
\hline
\end{tabular}

SE : Standard error. Statistically significant $p$-values are shown in bold.

Table III. Expression of phosphorylated insulin receptor 1 (IRS1) at week 9. Data from one rat in the group treated with $45 \mathrm{mg} / \mathrm{kg}$ streptozotocin were considered an outlier and omitted from the analysis. The differences between groups were analyzed using Mann-Whitney two-independentsample test.

\begin{tabular}{llllll}
\hline & & & \multicolumn{2}{c}{ Phosphorylated IRS1, pg/ml } & \\
Group & Treatment & $\mathrm{n}$ & Mean \pm SD & Range & $p$-Value $v s$. Control \\
\hline 1 & Control & & $1276.55 \pm 334.75$ & $799.31-1813.11$ & \\
2 & $25 \mathrm{mg} / \mathrm{kg}$ Streptozotocin & 8 & $1103.99 \pm 218.76$ & $820.88-1554.27$ & 0.834 \\
3 & $35 \mathrm{mg} / \mathrm{kg}$ Streptozotocin & 8 & $901.77 \pm 105.53$ & $842.45-1122.87$ & 0.141 \\
4 & $45 \mathrm{mg} / \mathrm{kg}$ Streptozotocin & 8 & $868.03 \pm 143.55$ & $756.17-1187.58$ & $\mathbf{0 . 0 1 5}$ \\
\hline
\end{tabular}

Statistically significant $p$-values are shown in bold.

Table IV. Correlation analyses between insulin receptor 1 (IRS1), fasting blood glucose (FBG) and area of Langerhans' islets. Correlation analyses were analyzed with Spearman's rho non-parametric correlation.

\begin{tabular}{lccc}
\hline Variable 1 & Variable 2 & Spearman's Rho & $p$-Value \\
\hline IRS1 & Islet area & 0.259 & 0.232 \\
IRS1 & FBG & -0.520 & $\mathbf{0 . 0 1 1}$ \\
Islet area & FBG & -0.603 & $\mathbf{0 . 0 0 2}$ \\
\hline
\end{tabular}

Statistically significant $p$-values are shown in bold.

indicated significant reduction of IRS1 in these streptozotocin-treated rats as compared to the control group ( $p=0.021$ and $p=0.017$, respectively).

Relationship among IRS1, area of Langerhans' islet and FBG in diabetic groups. Correlation of IRS1 with area of Langerhans' islet and FBG, as well as between FBG and area of Langerhans' islet were assessed in all HFD/streptozotocintreated rats $(n=23$; one datum in the group treated with streptozotocin $45 \mathrm{mg} / \mathrm{kg}$ was consider an outlier and omitted from the analysis). The results indicated a non-parametric distribution, thus the potential relationships were analyzed using Spearman's rho correlation test. As displayed in Table IV, the correlation analysis between IRS 1 and area of Langerhans's islet showed a weak correlation at $r=0.259$ $(p=0.232)$. IRS1 was significantly inversely correlated with FBG ( $\mathrm{r}=-0.520, p=0.011)$; inverse correlation indicated that a decrease in IRS1 was associated with an increase in FBG. The analysis of correlation between area of Langerhans' islets and FBG also showed a significantly inverse relationship ( $r=-0.603, p=0.002)$, indicating reduction of the area of Langerhans' islets was associated with an increase in FBG.

\section{Discussion}

In the present study, a total of 32 male Wistar rats were divided into four groups, consisting of one control group fed with basal diet and three diabetic groups. The three diabetic groups were fed with HFD for 4 weeks and injected with streptozotocin twice, at a weekly interval, with dose of 25,35 and $45 \mathrm{mg} / \mathrm{kg}$ BW. This was performed to mimic the condition of T2DM as HFD/streptozotocin administration leads to hyperinsulinemia, insulin resistance and severely reduced functionality of $\beta$-cells $(11,12,20)$. It has been suggested that streptozotocin injection generates reactive oxygen and nitrogen species, which are able to induce destruction of $\beta$-cells. Streptozotocin liberates toxic amounts of nitric oxide that participate in DNA damage and $\beta$-cells necrosis (26). The cytotoxic effect of streptozotocin on pancreatic $\beta$-cells is also due to depletion of intracellular ATP (27). Collectively, this results in a decrease in insulin biosynthesis and secretion $(28,29)$. 
Firstly, our findings showed a dose-dependent increment in FBG level. Of note, streptozotocin at doses of 35 and $45 \mathrm{mg} / \mathrm{kg}$ significantly increased FBG at week 9 ( $p<0.01$; Table I). The diabetic group treated with $45 \mathrm{mg} / \mathrm{kg}$ had a significantly higher FBG level as compared to the other groups (Table I). By using $140 \mathrm{mg} / \mathrm{dl}$ as a cut-off, both groups indeed had the same proportion of hyperglycemic rats (Figure 2). In general, the induction of T2DM performed by either a single injection of streptozotocin (19) or a combination of HFD and streptozotocin induces hyperglycemia and diabetes (21-23). It was initially reported that animal models of diabetes respond differently to streptozotocin injection using doses ranging from 25 to $100 \mathrm{mg} / \mathrm{kg}$ (21). A single dose of streptozotocin at 60 and $65 \mathrm{mg} / \mathrm{kg}$ established severe hyperglycemic condition associated with a depletion of pancreatic insulin content but these dosages were too toxic and can cause death to animals (20). Nonetheless, another study demonstrated that a combination of HFD and lower dose of streptozotocin as 35 $\mathrm{mg} / \mathrm{kg}$ stimulated natural disease progression and metabolic characteristics similar to those of T2DM (17). Taken together, these might serve as a rationale to use a low dose of streptozotocin in subsequent studies of T2DM.

Secondly, our results showed a dose-dependent reduction in the area of Langerhans' islets. Upon streptozotocin injections, the islets of Langerhans became smaller and irregular (Figure 3). Streptozotocin injection in diabetic rats reduces the number of $\beta$-cells, hence altering the shape and boundaries of Langerhans' islets $(16,20,30)$. Of note, a significant reduction in the area of Langerhans' islets was observed in the diabetic group injected with the highest dose of streptozotocin, as compared to those in the control group $(p<0.05$; Table II). Streptozotocin is a chemical toxin that induces prompt and irreversible necrosis of pancreatic cells (26) and administration of streptozotocin induces a partial loss of Langerhans' islet mass by necrosis (19). These facts would explain the dose-dependent reduction in the area of Langerhans' islet observed in this study.

Thirdly, our study demonstrated a dose-dependent reduction in the level of tyrosine-phosphorylated IRS1 in the diabetic groups. The decrease of IRS1 in the diabetic groups injected with streptozotocin at 35 and $45 \mathrm{mg} / \mathrm{kg}$ was statistically significant as compared to the levels observed in the control group $(p<0.05$; Table III). The mechanism underlying insulin resistance involves pro-inflammatory cytokines, e.g. tumor necrosis factor alpha and interleukin 6, which inhibit insulin receptor signaling and glucose transport (31). Decreasing levels of phosphorylated IRS1 have been observed in insulin-resistant states and were correlated with the hyperglycemic condition (32). Another study by Kulkarni et al. indeed demonstrated insulin resistance in Irs 1 knockout mice (33). Together with an elevation of blood glucose, insufficiency of IRS1 contributes to the pathogenesis of T2DM (8). Arguably, streptozotocin injection indirectly induces a reduction in phosphorylated IRS1.
Finally, by analyzing all data in the diabetic groups, we observed a moderate correlation between IRS1 and FBG, as well as between the area of Langerhans' islets and FBG (Table IV). As expected, both relationships were observed to be inversely correlated. It suggests that HFD and streptozotocin administration reduce functionality of $\beta$-cells partly through destruction of Langerhans' islets, resulting in reduction of released insulin. This in turn reduces the levels of phosphorylated IRS1, thus diminishing the efficiency of cellular uptake of blood glucose. Taken together, this resulted in increased levels of FBG in treated rats. We only found, however, a weak linear relationship between IRS1 and area of Langerhans' islets (Table IV). This might be due to an indirect connection between destruction of $\beta$-cells and reduced level of phosphorylated IRS1, as there might be several intermediate steps involved, e.g. level of secreted insulin. Further studies will be required to elucidate the exact relationship between these parameters.

\section{Conflicts of Interest}

The Authors have no conflicts of interest to declare.

\section{Authors' Contributions}

All Authors contributed to this study and the preparation of the article.

\section{Acknowledgements}

This study was funded by the Universitas Pelita Harapan's Research Foundation and was supported by the Mochtar Riady Institute of Nanotechnology, Karawaci, Tangerang. We expressed our gratitude to Professor Dr. George Mathew, Professor Dr.Irawan Yusuf and Dr. Ivet Suriapranata who kindly contributed to fruitful discussion of this study. We also appreciated input of Dr.Veli Sungono and Dr. Nikolaski Lumbuun, who reviewed the statistical analyses.

\section{References}

1 Wild S, Roglic G, Green A, Sicree R and King H: Global prevalence of diabetes: Estimates for the year 2000 and projections for 2030. Diabetes Care 27(5): 1047-1053, 2004. PMID: 15111519. DOI: 10.2337/diacare.27.5.1047

2 Yoon KH, Lee JH and Kim JW: Epidemic obesity and type 2 diabetes in Asia. Lancet 368: 1681-1688, 2006. PMID: 17098087. DOI: $10.1016 /$ S0140-6736(06)69703-1

3 King AJ: The use of animal models in diabetes research. Br J Pharmacol 166: 877-894, 2012. PMID: 22352879. DOI: 10.1111/j.1476-5381.2012.01911.x

4 Longo LD, Kasper DL, Jameson JL, Fauci AS, Hauser SL and Loscalzo J: Diabetes mellitus. In: Harrison's Principles of Internal Medicine 18 th Edition. New York: McGraw-Hill, 2011.

5 Rondinone CM, Wang LM, Lonnroth P, Wesslau C, Pierce JH and Smith U: Insulin receptor substrate (IRS) 1 is reduced and IRS-2 is the main docking protein for phosphatidylinositol 3kinase in adipocytes from subjects with non-insulin-dependent 
diabetes mellitus. Proc Natl Acad Sci USA 94: 4171-4175, 1997. PMID: 9108124. DOI: 10.1073/pnas.94.8.4171

6 Pederson TM, Kramer DL and Rondinone CM: Serine/threonine phosphorylation of IRS1 triggers its degradation possible regulation by tyrosine phosphorylation. Diabetes 50: 24-31, 2001. PMID: 11147790. DOI: 10.2337/diabetes.50.1.24

7 De Meyts P: The Insulin Receptor and Its Signal Transduction Network. [Updated 2016 Apr 27]. In: Feingold KR, Anawalt B, Boyce A and Dungan K (eds.). Endotext South Dartmouth (MA): MDText.com, Inc 2000. Available at: https://www.ncbi.nlm. nih.gov/books/NBK378978/ [Last accessed on August 12, 2020]

8 Lavin DP, White MF and Brazil DP: IRS proteins and diabetic complications. Diabetologia 59(11): 2280-2289, 2016. PMID: 27514532. DOI: $10.1007 / \mathrm{s} 00125-016-4072-7$

9 Kerouz NJ, Horsch D, Pons S and Kahn CR: Differential regulation of insulin receptor substrates-1 and -2 (IRS1 and IRS-2) and phosphatidylinositol 3- kinase isoforms in liver and muscle of the obese diabetic (ob/ob) mouse. J Clin Invest 100: 3164-3172, 1997. PMID: 9399964. DOI: 10.1172/JCI119872

10 Furman BL: Streptozotocin-induced diabetic models in mice and rats. Curr Protoc Pharmacol 70: 5.74.1-5.47.20, 2015. PMID: 26331889. DOI: $10.1002 / 0471141755$.ph0547s70

11 Kahn SE and Halban PA: Release of incompletely processed proinsulin is the cause of the disproportionate proinsulinemia of NIDDM: Diabetes 46: 1725-1732, 1997. PMID: 9356018. DOI: 10.2337/diab.46.11.1725

12 Lenzen S: The mechanisms of alloxan- and streptozotocininduced diabetes. Diabetologia 51: 216-226, 2008. PMID: 18087688. DOI: 10.1007/s00125-007-0886-7

13 McCan JAS: Understanding diabetes mellitus. In: Diabetes mellitus, A Guide to Patient Care. Munden J and Foley M (eds.). Philadelphia: Lippincott Williams \& Wilkins, p. 1-37, 2007.

14 Masharani U and German MS: Chapter 17: Pancreatic hormones \& diabetes mellitus. In: Greenspan's Basic and Clinical Endocrinology Ninth Edition. Gardner DG and Shoback D (eds.). New York: McGraw-Hill Medical, 2011.

15 Sun T, Han X: Death versus dedifferentiation: The molecular bases of beta cell mass reduction in type 2 diabetes. Semin Cell Dev Biol 103: 76-82, 2020. PMID: 31831356. DOI: 10.1016/ j.semcdb.2019.12.002

16 Elayat AA, El-Naggar MM and Tahir M: An immunocytochemical and morphometric study of the rat pancreatic islets. J Anat 186(3): 629-637, 1995. PMID: 7559135.

17 Srinivasan K, Viswanad B, Asrat L, Kaul CL and Ramarao P: Combination of high-fat diet-fed and low-dose streptozotocintreated rat: A model for type 2 diabetes and pharmacological screening. Pharmacol Res 52(4): 313-320, 2005. PMID: 15979893. DOI: $10.1016 /$ j.phrs.2005.05.004

18 Skovs $\emptyset$ S: Modeling type 2 diabetes in rats using high fat diet and streptozotocin. J Diabetes Investig 5(4): 349-358, 2014. PMID: 25411593. DOI: 10.1111/jdi.12235

19 Akbarzadeh A, Norouzian D, Mehrabi MR, Jamshidi SH, Farhangi A, Verdi AA, Mofidian SM and Rad BL: Induction of diabetes by streptozotocin in rats. Ind J Clin Biochem 22(2): 6064, 2007. PMID: 23105684. DOI: 10.1007/BF02913315

20 Pauzi NA, Muhammad AA, Fakurazi S, Arulselvan P and Ahmad Z: Preliminary study of the optimization of protocol for development of type 2 diabetic model in rats. Ind J Sci Technol 6(7): 4960-4965, 2013. DOI: 10.17485/ijst/2013/v6i7.20
21 Zhang M, Lv X, Li J, Xu Z and Chen L: The characterization of high-fat diet and multiple low-dose streptozotocin induced type 2 diabetes rat model. Exp Diabetes Res 2008: 1-9, 2008. PMID: 19132099. DOI: 10.1155/2008/704045

22 Reed MJ, Meszaros K, Entes LJ, Claypool MD, Pinkett JG, Gadbois TM and Reaven GM: A new rat model of type 2 diabetes: the fat-fed, streptozotocin-treated rat. Metabolism 49(11): 13901394, 2000. PMID: 11092499. DOI: 10.1053/meta.2000.17721

23 Magalhães DA, Kume WT, Correia FS, Queiroz TS, Allebrandt Neto EW, Santos MP, Kawashita NH and França SA: High-fat diet and streptozotocin in the induction of type 2 diabetes mellitus: A new proposal. An Acad Bras Cienc 91(1): 1-14, 2019. PMID: 30916157. DOI: 10.1590/0001-3765201920180314

24 Vital P, Larrieta E and Hiriart M: Sexual dimorphism in insulin sensitivity and susceptibility to develop diabetes in rats. J Endocrinol 190: 425-432, 2006. PMID: 16899575. DOI: 10.1677/joe.1.06596

25 Kolb H: Mouse models of insulin dependent diabetes: Low-dose streptozocin-induced diabetes and nonobese diabetic (NOD) mice. Diabetes Metab Rev 3: 751-778, 1987. PMID: 2956075. DOI: $10.1002 / \mathrm{dmr} .5610030308$

26 Szkudelski T: The mechanism of alloxan and streptozotocin action in B-cells of the rat pancreas. Physiol Res 50(6): 537-546, 2001. PMID: 11829314.

27 Nukatsuka M, Yoshimura Y, Nishida M and Kawada J: Importance of the concentration of ATP in rat pancreatic $\beta$-cells in the mechanism of streptozotocin-induced cytotoxicity. J Endocrinol 127(1): 161-165, 1990. PMID: 2151740. DOI: 10.1677/joe.0.1270161

28 Bedoya FJ, Solano F and Lucas M: N-Monomethyl-arginine and nicotinamide prevent streptozotocin-induced double-strand DNA break formation in pancreatic rat islets. Experientia 52(4): 344347, 1996. PMID: 8620938. DOI: 10.1007/BF01919538

29 Bolaffi JL, Nagamatsu S, Harris J and Grodsky GM: Protection by thymidine, an inhibitor of polyadenosine diphosphate ribosylation, of streptozotocin inhibition of insulin secretion. Endocrinology 120(5): 2117-2122, 1987. PMID: 2952491. DOI: 10.1210/endo-120-5-2117

30 Zhuo J, Zeng Q, Cai D, Zeng X, Chen Y, Gan H, Huang X, Yao $\mathrm{N}$, Huang D and Zhang C: Evaluation of type 2 diabetic mellitus animal models via interactions between insulin and mitogenactivated protein kinase signaling pathways induced by a high fat and sugar diet and streptozotocin. Mol Med Rep 17(4): 51325142, 2018. PMID: 29393432. DOI: 10.3892/mmr.2018.8504

31 Flanagan A, Brown J, Santiago C, Aad P, Spicer L and Spicer M: High-fat diets promote insulin resistance through cytokine gene expression in growing female rats. J Nutr Biochem 19(8): 505513, 2008. PMID: 17904344. DOI: 10.1016/j.jnutbio.2007.06.005

32 Hirosumi J, Tuncman G, Chang L, Gorgun CZ, Uysal KT, Maeda K, Karin M and Hotamisligil GS: A central role for JNK in obesity and insulin resistance. Nature 420: 333-336, 2002. PMID: 12447443. DOI: 10.1038/nature01137

33 Kulkarni RN, Winnay JN, Daniels M, Brüning JC, Flier SN, Hanahan D and Kahn RC: Altered function of insulin receptor substrate-1-deficient mouse islets and cultured $\beta$-cell lines. J Clin Invest 104: 69-75, 1999. PMID: 10606633. DOI: 10.1172/ JCI8339

Received October 8, 2020

Revised October 26, 2020

Accepted October 28, 2020 